\title{
TIDE DISTORTION AND ATTENUATION IN AN AMAZONIAN TIDAL RIVER
}

\author{
Paulo T. A. Freitas ${ }^{\text {; }}$ Odete F. M. Silveira ${ }^{2}$ and Nils Edvin Asp ${ }^{1 *}$
}

${ }^{1}$ Universidade Federal do Pará - Programa de Pós-graduação em Biologia Ambiental - (PPGBA-UFPA) (Campus Bragança, Alameda Leandro Ribeiro, s/n, 68600-000 Bragança, PA, Brasil)

${ }^{2}$ Instituto de Geociências - Universidade Federal do Pará (IG-UFPA) (Campus Guamá, Rua Augusto Corrêa, 01, 66075-110 Belém, PA, Brasil)

*Corresponding author: nilsasp@ufpa.br

\section{A B S T R A C T}

The present study seeks to evaluate tidal propagation in the Guamá-Capim river system, in the Amazonian region, considering hydrodynamic and geomorphological aspects. Available data sets on fluvial discharge and water level variations were considered, besides several methods of measuring the tides (currents, water levels and discharges) recorded at different stations and in different periods. The main point argued is that fluvial discharge is the key-factor in tidal distortion and tidal bore formation in the system investigated, whereas the low relief of the area would be the main factor contributing to landward tidal incursion. The results show an impressive upward tidal incursion of more than $200 \mathrm{~km}$, including substantial distortion - increasing upstream - of the tidal wave, of which the ebb phase lasts up to 5 hours longer than the flood, including higher flood current velocities as far as $161 \mathrm{~km}$ upstream. Generally, only hyposynchronous tidal response was observed. Seasonally, the fluvial discharge varies about 10 times in the Guamá and 4 times in the Capim River. The increase of the fluvial discharge results in an increasing distortion of the tide, besides a weak increase of the attenuation. During high fluvial discharge periods in conjunction with equinoctial tides (e.g. MarchApril), a tidal bore occurs in the system, also increased by the generally low relief. Therefore, the conclusions include: low relief and the distortion related to high fluvial discharges are the main factors controlling tidal propagation along the system and tidal bore formation. Furthermore, the system could be classified as a tidal river, in which massive regional fresh water input results in virtually non-existent salinity throughout the Guamá-Capim system.

\section{R E S U M O}

O presente estudo teve como objetivo investigar a propagação da maré no sistema fluvial GuamáCapim, na região amazônica, considerando aspectos hidrológicos e geomorfológicos. Os métodos empregados incluem dados históricos de vazões fluviais e níveis d'água, além de medições próprias de maré em diferentes locais e períodos ao longo do sistema. Os principais pontos defendidos no presente trabalho incluem a vazão fluvial como principal fator para a distorção da maré e consequente formação de pororoca no sistema, assim como o baixo relevo da área seria responsável por incremento na incursão da maré para o continente. Os resultados revelam uma penetração da maré de mais de $200 \mathrm{~km}$, ocorrendo também uma forte deformação da maré, se intensificando gradualmente a montante, resultando em uma vazante até 5 horas mais longa que a enchente $161 \mathrm{~km}$ a montante, apresentando também velocidades de enchente levemente superiores, incluindo o decaimento contínuo da altura da maré, intensificado a partir desse ponto. Sazonalmente, a vazão fluvial aumenta 10 vezes no rio Guamá e 4 vezes no rio Capim. Durante períodos de alta descarga, combinados com marés equinociais (e.g. março-abril), o fenômeno da pororoca ocorre no sistema, em associação ao baixo relevo da área. Desta forma as principais conclusões são de que a forte deformação da maré relacionada a altas descargas fluviais e o baixo relevo da área são os fatores preponderantes na propagação da maré no sistema e formação de pororoca. Mais além, o sistema foi classificado como tidal river, onde a enorme descarga de água doce na região costeira amazônica resulta na prática ausência de salinidade no sistema estudado. Assim, seu estudo vem contribuir na definição e classificação de sistemas estuarinos.

Descriptors: Fluvial discharge, Tide propagation, Tidal rivers.

Descritores: Vazão fluvial, Propagação da maré, Rios de marés.

\section{INTRODUCTION}

Estuaries are one of the most complex and intriguing targets of scientific studies in various research fields around the world, being the subject of discussion regarding definitions, classifications and subdivisions since the mid- $20^{\text {th }}$ century. Common knowledge simply regards estuaries as the coastal 
portions of rivers substantially influenced by the sea into which they flow. As distinct from fluvial deltas, it can be said that in an estuary, the landward influence of marine forces (e.g. tides) is more evident than the opposite. However, due to different geological, physical, chemical and biological processes which determine estuarine characteristics, origin and evolution, the definition and classification of these coastal environments is not a simple task and their study in the search for more concise understanding, has been highly interdisciplinary.

The majority of studies on the definition and classification of estuaries were developed primarily in Europe and North America (PRITCHARD, 1955; CAMERON; PRITCHARD, 1963; PRITCHARD, 1967; HANSEN; RATTRAY, 1966; NICHOLS; BIGGS, 1985; DALRYMPLE et al., 1992). Their classical definitions and classifications are still applied worldwide, including that of the Amazon Coastal Zone (ACZ) where several estuaries, the subject of recent important studies, are found and in which a macrotidal regime and the Amazon River dominate the regional scenario.

The Amazon River has a maximum water discharge of around $200 \times 10^{3} \mathrm{~m}^{3} \mathrm{~s}^{-1}$ and suspended sediment load of the order of $3.5 \times 10^{6}$ tons per day (MEADE et al., 1985). At the present time, the Amazon sediment plume is mainly driven northwards, in association with the Guyana current (LENTZ, 1995). On the other hand, other rivers of the region seem to have but secondary relevance as regards the sediment supply to the coastal zone, but the various estuaries associated with the rivers are important as sediment traps.

An important distortion in tide propagation occurs within the estuaries along the ACZ, substantially affecting the sediment transport along the river-estuary-ocean continuum. However, there are substantial variations between the different estuaries, as a consequence of the relative size of the catchment areas (i.e. as affecting their fluvial discharge), storage capacity (size of intertidal/mangrove areas) and general geomorphological configuration. Furthermore, there is a strong overall seasonal variation in the fluvial discharge, as a consequence of the regional climate, which is determined mainly by seasonal changes in the position of the Inter-tropical Convergence Zone (ITCZ), including the high precipitation in the first months of the year. This pattern results in substantial seasonal variations in fluvial discharge which during the rainy season is 10 to 20 times (in terms of monthly averages) larger than that of the dry season (ANA, 2011).

Nevertheless, these processes have still not been deeply investigated in the Amazon region. In some of the dozens of estuaries existing in the region, the processes mentioned affecting tidal propagation result in events such as tidal bores, as occurs in the Guamá-Capim river system, highlighted in this study. Salt intrusion and its vertical/longitudinal gradients also present important spatial and temporal differences between neighboring estuaries.

Within the theme of this paper, some important work has already been produced on the area, who identified the absence of salinity at the Guamá river mouth and very low values in the Guajará Bay, into which it empties. Furthermore, there is no information on salt intrusion upstream.

An important study on the area has been undertaken by Gregório and Mendes (2009), including the analysis of the sedimentary deposits and bottom morphology of the Guajará Bay and Guamá mouth. The authors have identified the strong action of tidal and river currents causing intense erosive processes, as also reported. Based on the definition proposed by Wells (1995), Gregório and Mendes (2009) have classified the Guajará Bay as a Tidal River, where tidal effects are substantial, but no sea water (salt intrusion) is to be observed.

Rossetti and Santos-Júnior (2004) have carried out an important stratigraphic investigation approximately 250 kilometers upstream from the Guajará Bay, along the Capim River, based on the analysis of sedimentary sequences exposed by the mining activities on the banks of the river. The information extracted revealed the tidal action evidenced by the sedimentation processes in deposits from the Miocene (Tertiary). The above-mentioned data and the geographical setting of the area reveal that tidal propagation extended at that time many kilometers further upstream than it does today, probably in association with old marine transgressions. Furthermore, considerable channel meandering has taken place since that period, by reason of which the deposits described are now found 4 kilometers away from the present Capim River thalweg. Besides, there is no reported paleontological information which supports or refutes salt intrusion up to the referred area enabling one to classify the past system either as a tidal river or a typical macrotidal estuary.

The term "tidal river" might have been introduced by Cohen and McCarthy (1963), though it was also applied later by Kjerfve and Magill (1989) and Kjerfve (1994) to the lower reaches of fluvial valleys subject to tidal action though without saline intrusion. Later, Wells (1995) defined tidal rivers as a special case of macrotidal estuaries into which the tide penetrated much further than the salt and dissociated from it. The Amazon and La Plata rivers are quoted as examples. However, these characteristics are also found in many of the typical macrotidal estuaries.

Further, several authors have also applied the term to estuaries where river flow is of great significance (CHAPPELL; WOODROFFE, 1994; 
CHUN-YAN; O’DONNELL， 1998; SHIH，2002; VRIEND, 2003; CARR et al., 2004). Sometimes the term tidal river also appears as a synonym for "riverdominated estuaries" or even for the uppermost part of an estuary, beyond any detectable salinity, but with tidal co-oscillation (COOK et al., 2007).

Emeka et al. (2010) have made an important contribution to the definition and applicability of the term tidal river by their investigations into such environments in Nigeria, Africa. The authors postulated that a tidal river does not empty directly into the ocean, for instance.

Based on existing literature and the observed environmental characteristics of the study area, it is believed that the term tidal river can properly be applied to several environments within the Amazon Coastal Zone (ACZ). A tidal river is, therefore, here defined as a fluvial environment subject to dynamic tidal action, without salt intrusion and which does not empty directly into the ocean, being part of a larger estuarine system, especially one dominated by macrotides (e.g. Marajó Bay Estuary/Pará River) and extending from the river mouth up to the Tidal Limit Zone inland. Conceptually, tidal rivers might be considered as intermediate between typical macrotidal estuaries and tidal-dominated river deltas. The definition adopted here is strongly supported by the work of Emeka et al. (2010).

Furthermore, the efforts summarized in the present study focus on the interaction of river flow and tidal propagation within a system where both factors are intense, going further than the pure search for a conceptual definition or classification of tidal rivers. A similar study has been conducted by Kosuth et al. (2009) on the Amazon River, also motivating the present investigation.

The authors of this present paper support the classification of the Guamá-Capim river system as a tidal river, as it presents typical Amazonian characteristics, such as high fluvial discharge, low relief, extensive dynamic tidal action and substantial seasonality.

The aim of this study is, therefore, to highlight the hydrodynamic processes involved in the tidal propagation along the Guamá-Capim fluvial system, based mainly on field measurements of discharge, currents, water levels and basin hypsometry. The main argument presented is that fluvial discharge is the key-factor to tidal bore formation in the investigated system, whereas the low relief is the main factor determining the impressive landward tidal incursion. Further, the results obtained are used to propose a discussion on estuarine classifications and the relevance of fluvial discharge for estuarine hydrodynamics.

\section{Material and Methods}

\section{Study Area}

The study area is located on the northern coast of Brazil and focused on the Guamá-Capim tidal river system (Fig. 1). The mouth of the river system studied is located about $130 \mathrm{~km}$ from the Atlantic Ocean, emptying into the so-called Guajará Bay, which also receives the Mojú and Acará rivers and has a drainage area of approx. 87,400 $\mathrm{km}^{2}$ (GREGÓRIO; MENDES, 2009). Further, the Guajará Bay itself empties into the Marajó Bay, which receives a large fresh water discharge from the Tocantins and Pará rivers, besides the Guajará Bay.

The tides in the eastern sector of the Amazon coast semidiurnal tide region reach ranges of 4 to $5 \mathrm{~m}$ along the coast and up to $6 \mathrm{~m}$ in the estuaries during spring tides (SOUZA- FILHO et al., 2003).

The wide, funnel-like shape of the Marajó Bay makes the substantial tidal incursion throughout the system possible, although the fluvial discharges mentioned maintain low to zero salinity in the Bay, depending on the season rainfall and resulting fluvial discharge (BEZERRA et al., 2011).

As has already been mentioned, the climate on the Amazon coast is determined mainly by seasonal changes in the position of the Inter-tropical Convergence Zone (ITCZ), which is situated in latitudes around $14^{\circ} \mathrm{N}$ during August and September, migrating southwards as far as around $2^{\circ} \mathrm{S}$, exactly over the Amazon region, during March and April (SOUZA-FILHO et al., 2009). Thus the region experiences heavy rainfall in the first months of the year, with $73 \%$ of the total annual fall occurring between January and April, while September, October and November are especially dry months (MORAES et al., 2005). The annual regional rainfall is high, thus contributing to estuarine development, and varies from 2,300 to $2,800 \mathrm{~mm}$ (MORAES et al., 2005), the rainiest month usually being March and the driest October. However, inter-annual variations are considerable.

Further, there are also important local spatial variations in precipitation, whereby the area surrounding the Marajó Bay may be classified as "without a dry season", since during the driest months rainfall is still as intense as 100-150 mm (ANA, 2011). On the other hand, to the south and east of the Marajó Bay, where the sources of the Guamá-Capim river system are located, precipitation is of the order of 20$30 \mathrm{~mm}$ during the dry period, which might last as long as 5 months. During the rainy months, precipitation is of the order of 400-500 mm overall (MORAES et al., 2005). 


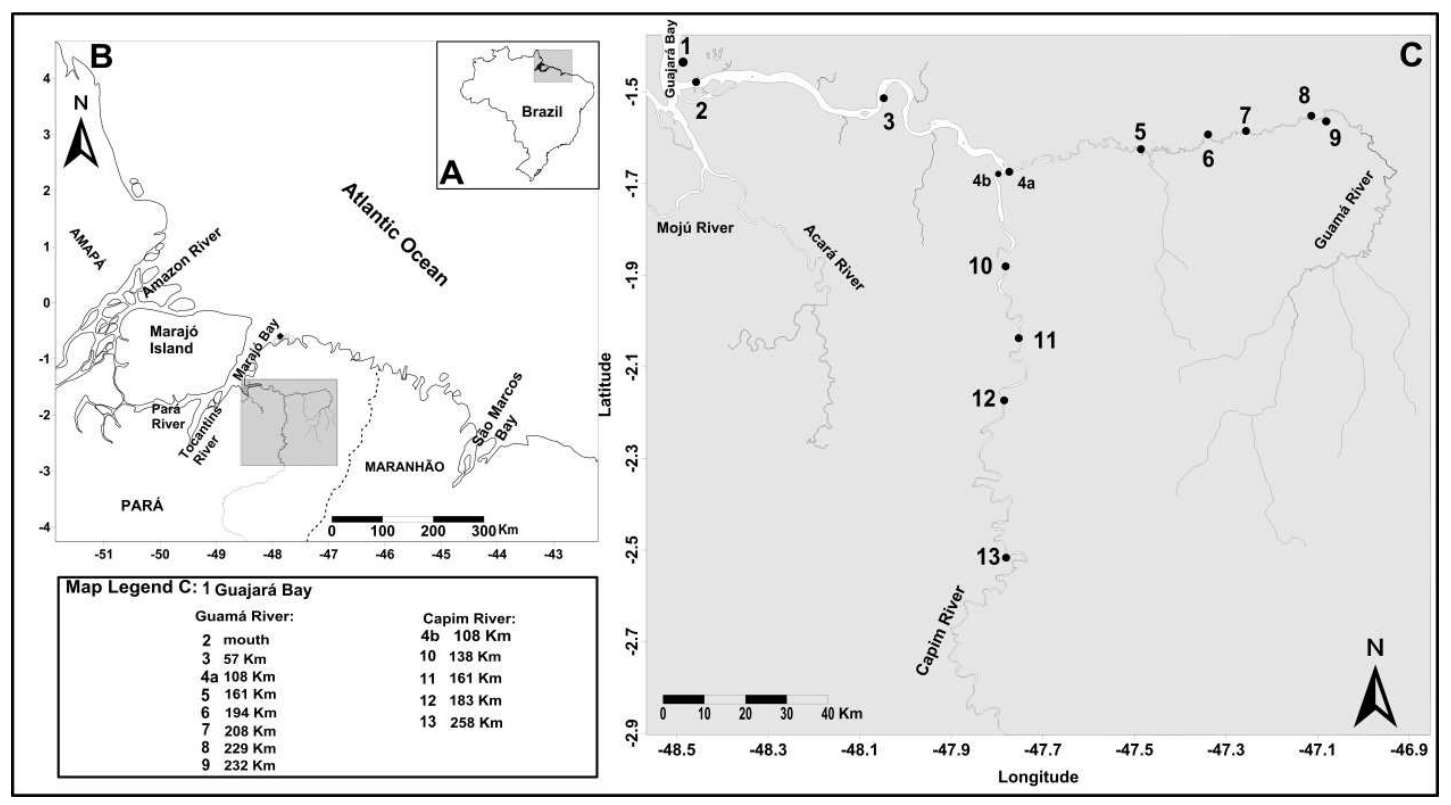

Fig. 1. Study area location and positions of the sampling stations (distances along the river course).

The database used in this study was built up through field activities, in addition to incorporating a variety of time series data on water levels, depths and currents from the AHIMOR (Eastern Amazonian Waterways Administration), data from the tide gauges of the DHN (Brazilian Navy's Hydrography and Navigation Directory) and the hydrometric stations of ANA (Brazilian Water National Agency). The rainfall and fluvial discharge time series used here were obtained for the Guamá (km 232 / point 9 - Bom Jardim Station) and Capim ( $\mathrm{km} 258 /$ point $13-$ Badajós Station) rivers (Fig. 1), beyond tidal influence (ANA, 2011).

Further, the measurements carried out as part of this study include variation of water level (tide), currents and discharge in different periods and at different locations along the river channels.

As regards the measurements taken in 2010 (June and September), water level variation was monitored initially (in June) using a centimetergraduated scale on the Guamá River at points $4 \mathrm{a}(\mathrm{km}$ 108), 5 (km 161), 7 ( km 208) and 8 (km 229), whereas later (in September) pressure sensors developed by Solar Instrumentação ${ }^{\mathrm{TM}}$ model SL2000 were installed at $4 \mathrm{a}(\mathrm{km} \mathrm{108)}, 5(\mathrm{~km} \mathrm{161)}$, and $6(\mathrm{~km} \mathrm{194)})$ as presented in Figure 1. In all cases water levels were measured every 10 seconds and averaged/recorded every 5 minutes for a minimum period of 13 hours. Further, at each point measured water levels were referred to the local mean water level.
Currents were also measured at the points referred to above with an Acoustic Doppler Current Profiler (ADCP - Teledyne RDI ${ }^{\mathrm{TM}}$ ) model Workhorse $1200 \mathrm{kHz}$ during complete tidal cycles. The ADCP was mounted on a boat, undertaking cross-sectional profiles continuously. Due to the entire cross-section measurements, along/cross-stream component analysis was dispensable and cross-sectional averages of current velocities were obtained directly.

The ADCP settings used mostly follow the default configuration and are suitable to the conditions in the areas measured. They include a mean sampling frequency of $1.5 \mathrm{sec}$. (deltatime) and a bin size of 0.25 $\mathrm{m}$. Most cross-sections were covered in 1 to 5 minutes, with the exception of the measurements made at the system's mouth, which took up to 15 minutes. The unmeasured top and bottom parts of the velocity profile were estimated using the power method with the default value of $1 / 6$ for power. On the other hand, the near-shore unmeasured velocities and discharge were estimated on the basis of a triangular shape and a coefficient of 0.35 for decay, based on the last ensemble measured and the equipment-shore distance, which was measured using a digital laser distance meter DLE-70 (Bosch).

Similarly, during the years 2008 and 2009 four seasonal measuring campaigns (October/08, January, April and July/09) for currents and discharge were undertaken at the Guamá river mouth (point 2), to evaluate the effects of fluvial discharge variations in an essentially tidal sector of the system. 
Therefore, the water level and current data sets used here cover diverse periods (rainy to dry season, neap to spring tidal cycles) from the years 1998, 1999, 2008, 2009 and 2010, as summarized in the table below (Table 1).

Table 1. Temporal and spatial coverage of the data used in this paper.

\begin{tabular}{|c|c|}
\hline PERIOD & $\begin{array}{c}\text { KIND OF MEASUREMENT } \\
\text { AND LOCATION }\end{array}$ \\
\hline $\begin{array}{l}1998 \text { (Dec) }-1999 \\
\text { (May and July) }\end{array}$ & $\begin{array}{l}\text { water levels: river mouth to km } \\
183 \text { upstream, on both Guamá } \\
\text { and Capim Rivers }\end{array}$ \\
\hline $\begin{array}{l}2008 \text { (Oct) }-2009 \\
\text { (Jan, Apr and Jul) } \\
2010 \text { (Jun and Sep) }\end{array}$ & $\begin{array}{l}\text { discharge and currents at Guamá } \\
\text { River mouth } \\
\text { discharge, currents and water } \\
\text { levels on Guamá and Capim } \\
\text { Rivers }\end{array}$ \\
\hline
\end{tabular}

The ACDP data were initially analyzed using the equipment software WINRIVER II, considering mainly cross-sectionally averaged current velocities and discharges. Further, data were also analyzed and correlated using a conventional electronic worksheet, on which the different data sets were represented graphically and correlated.

River basin limits, courses and thalweg elevations were established based on satellite images (Landsat 5TM and ALOS PALSAR, with $10 \mathrm{~m}$ and 15 m resolution) and SRTM (Shuttle Radar Topography Mission) data, including approx. $90 \mathrm{~m}$ of spatial and 1 $m$ of vertical resolution (JARVIS et al., 2008).These data was also used to develop a Digital Elevation Model (DEM), used then to carry out the hypsometric analysis. The DEM was built up using the software Surfer ${ }^{\circledR}$ v.9.3, where the interpolation method used was triangulation with linear interpolation, including $200 \mathrm{~m}$ of grid spacing. The relationship of area and elevation of each basin analyzed was graphed as hypsometric curves, enabling geomorphological comparisons to be made between the basins, especially based on the classic work of Strahler (1952), where further details about the method are to be found.

\section{Results}

\section{Seasonality and fluvial discharge}

As mentioned, points 13 (Capim River) and 09 (Guamá River), correspond to hydrometric stations of the ANA (2011), where precipitation and fluvial discharge are monitored. The results corresponding to the years of interest are presented in Figures 2 and 3, respectively. Although the dataset considered represents 20 years of daily recordings, there are several gaps in the time series. Nevertheless, only consistence-checked data were considered.
It may be observed that at points 09 (Fig. 3) and 13 (Fig. 2) the general rainfall pattern is similar, there being is a clear distinction between the rainy season, in the first half of the year, and the dry season, in the second half of the year. However, the rainy season at point 13/Badajós Station (Capim River) lasts from December to May, whereas at point 09/Bom Jardim Station (Guamá River) it includes the period from January to May. On the other hand, the dry season can be considered as lasting from July to October for the Capim, and August to November for the Guamá River, despite the existence of transition periods.

Besides, during the rainy season monthly mean precipitation is around $400 \mathrm{~mm}$ in the Capim River area and $300 \mathrm{~mm}$ for the Guamá River area. During the dry season these values are about 30 and $50 \mathrm{~mm}$ for the Capim and Guamá Rivers, respectively.

Furthermore, rainfall results show very high values for April-May/2009, which could be related to the effects of the La Niña event in the region. According to Marengo et al. (2011), El Niño and La Niña events may often have serious environmental consequences for the whole Amazon region. In fact, the rainfall at the Badajós Station (Capim River) attained around $650 \mathrm{~mm}$ in May/2009 and $570 \mathrm{~mm}$ in April/2009 at Bom Jardim Station (Guamá River).

Figures 2 and 3 illustrate the daily-averaged fluvial discharge in non-tidal sectors over 20 years, showing substantial seasonality (Figs $2 \mathrm{~B}$ and $3 \mathrm{~B}$ ), with a clear difference between the high discharge period (March - June) and the low discharge period (September - December), including transitional periods. As expected, the fluvial discharge is closely linked to the seasonality of rainfall in the region (Figs $2 \mathrm{~A}$ and $3 \mathrm{~A})$.

Besides, great interannual variation, including shifts of the rainy season, duration and intensity variations, can also be observed. Nevertheless, both discharge and rainfall show a clear quantitative difference over the year, registering the highest discharges during May, as a reflection of the heavy rains in the first months of the year, reaching their peak mainly during the months of March and April.

It can be observed that during the wet season the discharge maximum of the Capim River varies from 700 to $1,700 \mathrm{~m}^{3} / \mathrm{s}$, whereas in the dry season it is between 200 and $400 \mathrm{~m}^{3} / \mathrm{s}$. The discharge maximum of the Guamá River during the wet season reaches 250 to $600 \mathrm{~m}^{3} / \mathrm{s}$. During the dry season the discharge is around 20 to $50 \mathrm{~m}^{3} / \mathrm{s}$. The total fluvial discharge of the Capim River is, therefore, up to 3 times greater than that of the Guamá. In the dry season the Capim River usually accounts for $9 / 10$ of the total fluvial discharge of the system. 


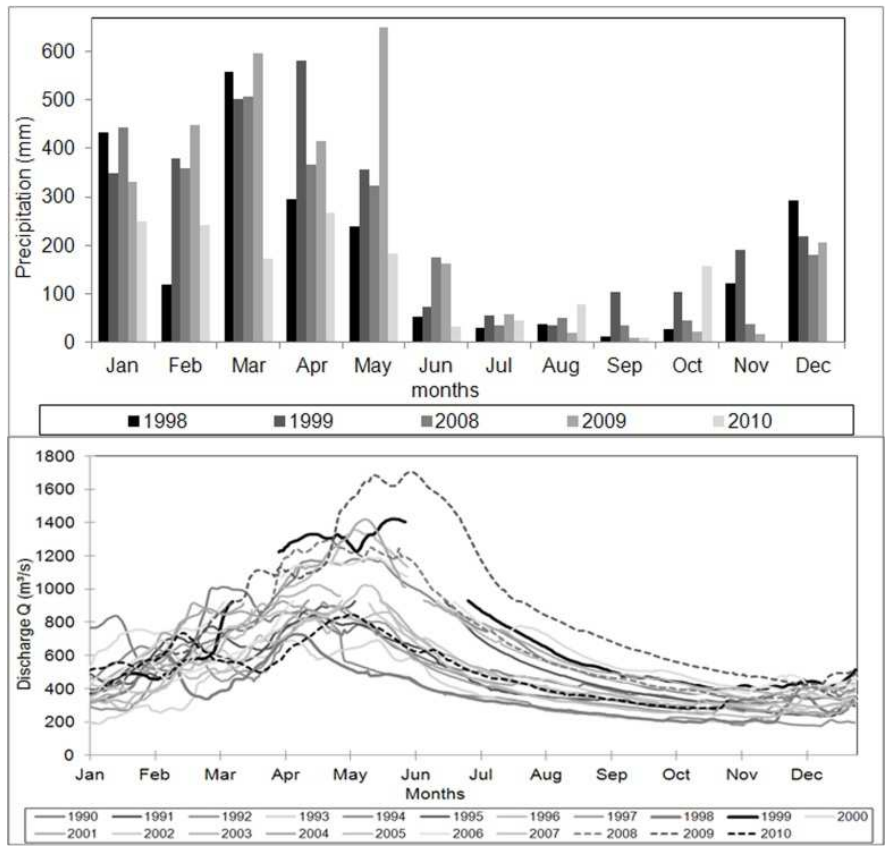

Fig. 2. Precipitation and fluvial discharge time series recorded at Capim River (point 13 / km 258), from ANA hydrometric station. (A) Precipitation for the analyzed years and (B) discharge over the last 20 years (1990-2010).

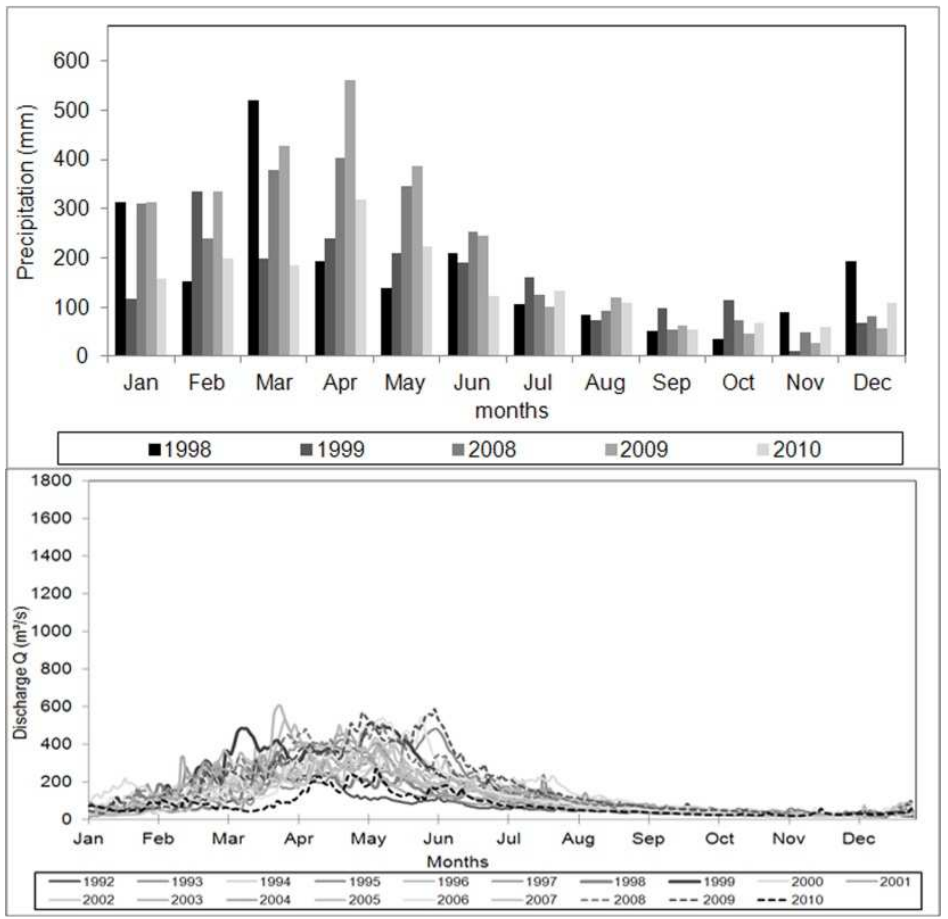

Fig. 3. Precipitation and fluvial discharge time series recorded at Guamá River (km 232 / point 9), from ANA hydrometric station. (A) Precipitation for the analyzed years and (B) discharge over the last 20 years (1990-2010). 
Tidal Damping and Distortion

Figure 4 illustrates the propagation of the tidal wave along the Guamá-Capim river system under spring and neap conditions during high discharge (A $\mathrm{B})$, mean (moderate) discharge $(\mathrm{C}-\mathrm{D})$ and low discharge periods $(\mathrm{E}-\mathrm{F})$.

In general, it can be observed that both tidal range and upstream tide incursion decrease with increasing fluvial discharge. At $\mathrm{km} 183$ (point 12), tidal range reaches values of around $0.9 \mathrm{~m}$ during lowdischarge periods, whereas tidal variation was not detected during high-discharge periods and a variation of only a few centimeters was observed under meandischarge conditions.

The measurements indicate that the tidal incursion could reach up to $200 \mathrm{~km}$ inland during lowdischarge periods, and even during high-discharge periods a tidal variation of around $0.7 \mathrm{~m}$ was detected at $161 \mathrm{~km}$ from the river mouth. There, the tidal range attains values of around $3.2 \mathrm{~m}$ during spring tides, where fluvial discharge seems to have little influence. During neap tides the range was around $2.3 \mathrm{~m}$ during high-discharge and $2.7 \mathrm{~m}$ during low-discharge periods.

Measurements during spring equinoctial tides on the Guamá River and during low-discharge periods (Fig. 5) show a similar pattern, as described for the Capim River (Fig. 4). Under this extreme condition, tidal range was around $3.8 \mathrm{~m}$ at the river mouth and the tidal incursion certainly advances more than $200 \mathrm{~km}$ upstream, where a tidal range of around 1 $\mathrm{m}$ was measured at $\mathrm{km} 194$ (point 6).

It could also be observed that at all the measuring points the ebb-to-flood transition occurs very quickly, unlike the inverse process, where the flood-to-ebb transition occurs gradually. The tidal wave also becomes progressively more asymmetrical upstream on both the Capim (Fig. 4) and Guamá rivers (Fig. 5).

As regards the Capim River at spring tide, generally the tidal range decreases around $0.5 \mathrm{~m}$ every $50 \mathrm{~km}$, and the ebb phase becomes about $1.17 \mathrm{~h}$ longer than the flood along the same stretch of the river's course. A maximum phase duration difference of around $5 \mathrm{~h}$ is observed at $\mathrm{km} 161$ (point 5), including variations in neap tidal cycles and also when high- and low-discharges are compared (Fig. 4).

It may be observed in Figure 4 that on the Capim (A) as well as the Guamá River (B) the tidal range decreases gradually upstream. However, there is a substantially greater decrease from $\mathrm{km} 108$ (point 4) onwards.

Figure 6 summarizes the tidal range variation presented in Figures 4 and 5, for the Capim (Fig. 6A) and Guamá rivers (Fig. 6B). As is to be expected, tidal range decreases with increasing river discharge (Capim River, Figure 06A). On the Guamá River, the measurements indicate that the attenuation of the upstream tidal range is gentler than on the Capim River, at least during low-discharge periods (Fig. 6B).

However, these measurements correspond to a spring tide situation, under equinoctial effects and with low fluvial discharge. Thus, tidal range attenuation can be assumed to be minimal. Even hypersynchronicity might occur under these conditions, since the tide could be amplified between the mouth and $\mathrm{km} 108$ (point 4), for which, unfortunately, there are no data available. Indeed, the tidal range observed was virtually the same at $\mathrm{km} 57$ as at $\mathrm{km} \mathrm{108,} \mathrm{under}$ mean-discharge conditions ( $14^{\text {th }}$ Jul 1999, Figure 6A).

According to the simultaneous water level measurements at different points along the channel, the tidal wave requires about $9 \mathrm{~h}$ to move from Guajará Bay up to km 183 on the Capim River in the low-discharge period (Fig. 7A). In the high-discharge period the advance of the tide is very similar, although tidal variation was detected only up to $\mathrm{km} 161$ (point 5). On the Guamá River, the tidal wave requires about $8.5 \mathrm{~h}$ to move upstream from Guajará Bay to km 194. Furthermore, it could be observed that in the lowdischarge period and under equinoctial influence the tide advances faster in the uppermost portion of the tidal river, where fluvial discharge is very significant to the circulation.

Concerning the water level and flow measurements taken at $\mathrm{km} 108$ - Capim River (point $4 \mathrm{~b}$ - Figure 8) and the Guamá River (point $4 \mathrm{a}$ - Figure 9) confluence, the patterns of current velocity, discharge and water level variation did not differ substantially between the mean- and low-discharge periods.

As expected, there was a significant increase in the relative flood discharge and current velocity during the low-discharge period. In this case, the flood velocity maximum is about $18 \%$ higher than the ebb current velocity maximum on the Capim River (point $4 \mathrm{~b})$. During the mean-discharge period, the flood current velocity maximum was around $9 \%$ higher than at the ebb. On the Guamá River (point 4a) these differences were even bigger, as the flood velocity maximum was $30 \%$ higher than the ebb current velocity maximum. During the mean-discharge period the flood current velocity maximum was around $16 \%$ higher than at the ebb.

Since the measurements were taken during the conjunction of the low-discharge period and equinoctial effects, the tidal range was about $33 \%$ higher in this situation. Thus, current velocities were proportionally higher. 


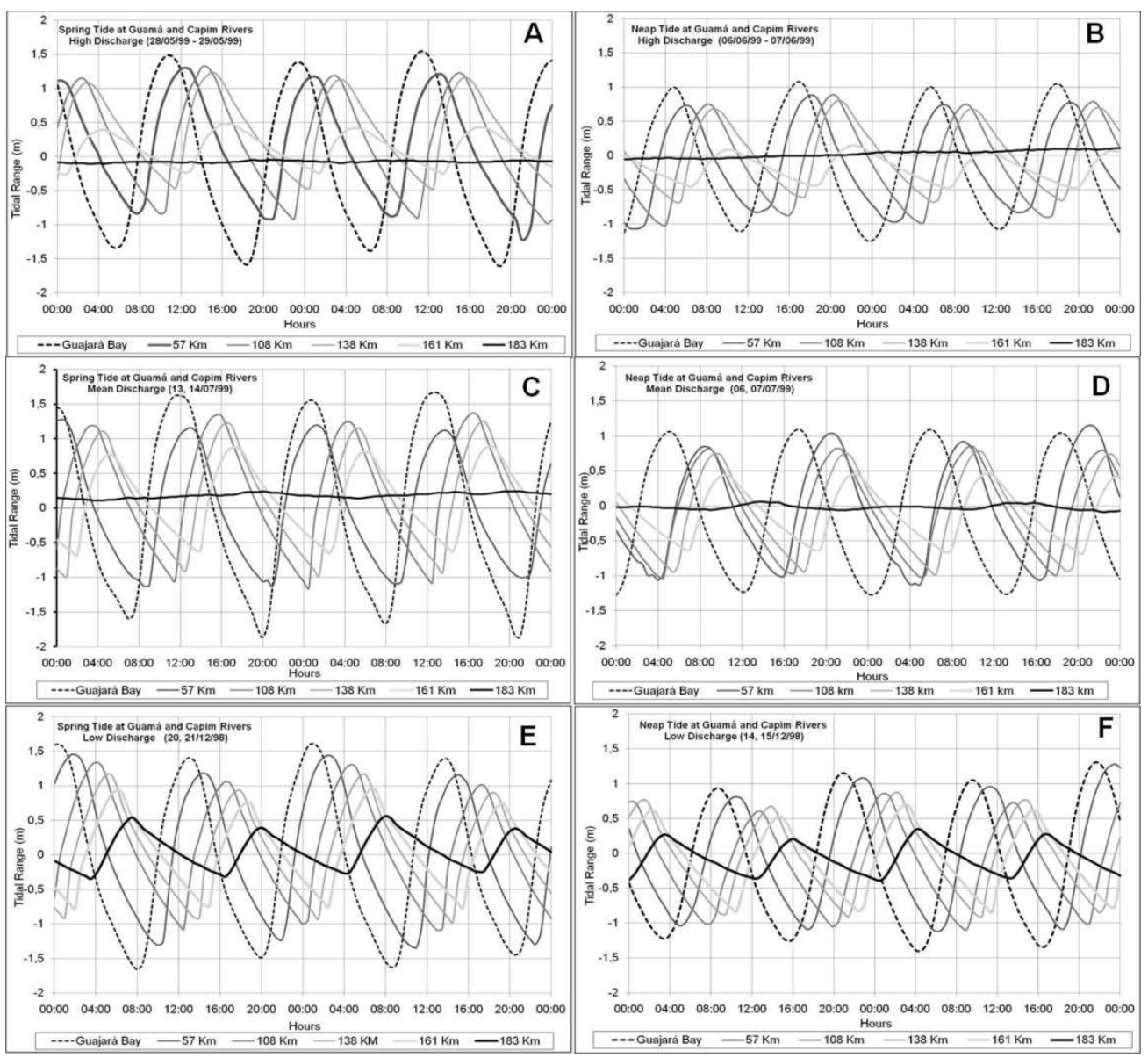

Fig. 4. Spring (A, C and E) and neap (B, D and F) tidal cycles recorded at Guajará Bay and Guamá-Capim river system during high-discharge (A-B), moderate-discharge (C-D) and low-discharge (E-F) periods.

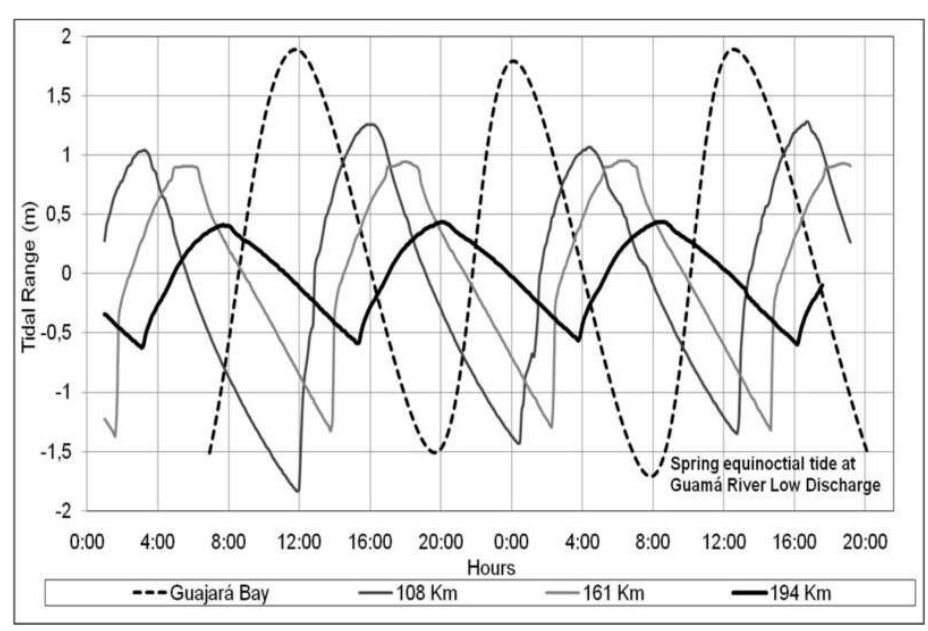

Fig. 5. Equinoctial spring tide cycles recorded at Guamá River $\left(09^{\text {th }}\right.$ and $10^{\text {th }}$ Sep 2010), since the Guajará Bay up to 194 km. 

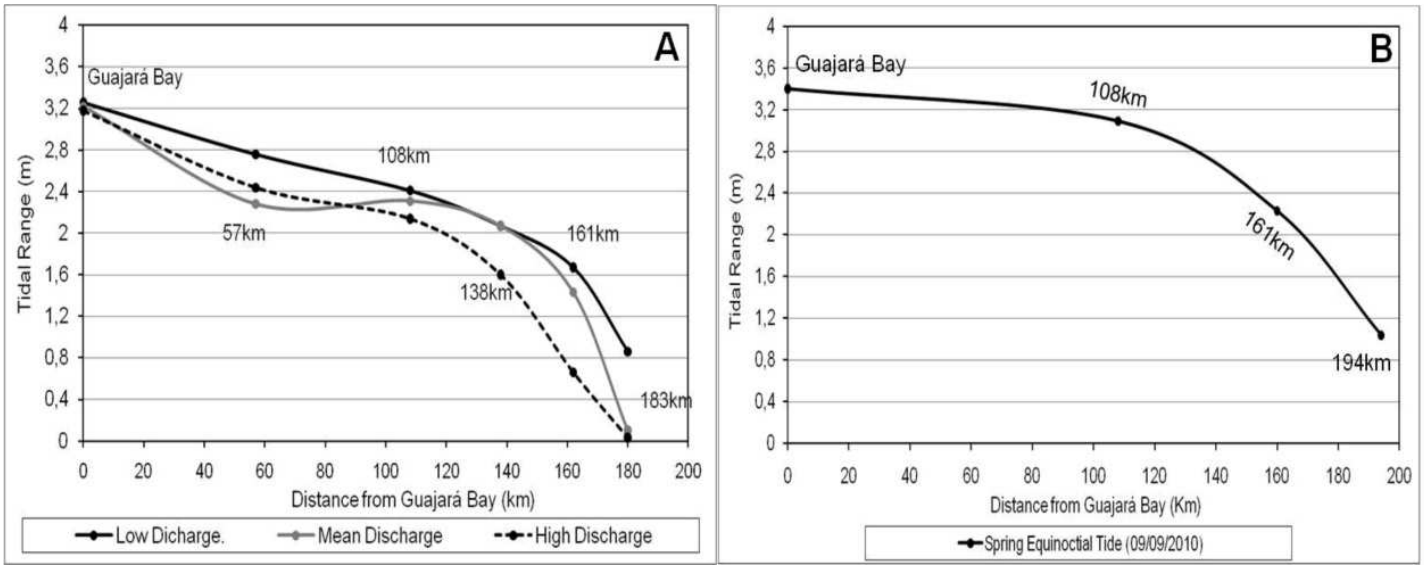

Fig. 6. (A) Tidal wave attenuation along the Guamá-Capim system at low (20/12/1998), mean (14 $4^{\text {th }} J u 1$ 1999) and high (30 $0^{\text {th }}$ May 1999) discharge stages; and (B) Tidal wave attenuation along the Guamá River at spring equinoctial tide $\left(09^{\text {th }}\right.$ Sep 2010$)$.
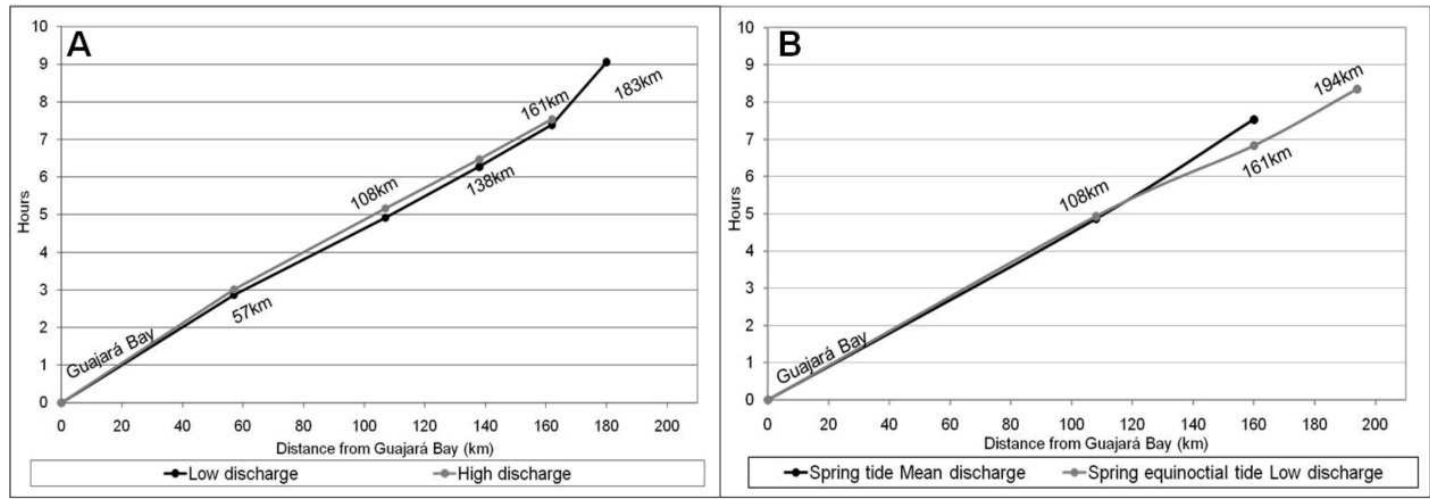

Fig. 7. Propagation time and tidal-wave incursion along the Guamá-Capim system (A) and Guamá River (B).
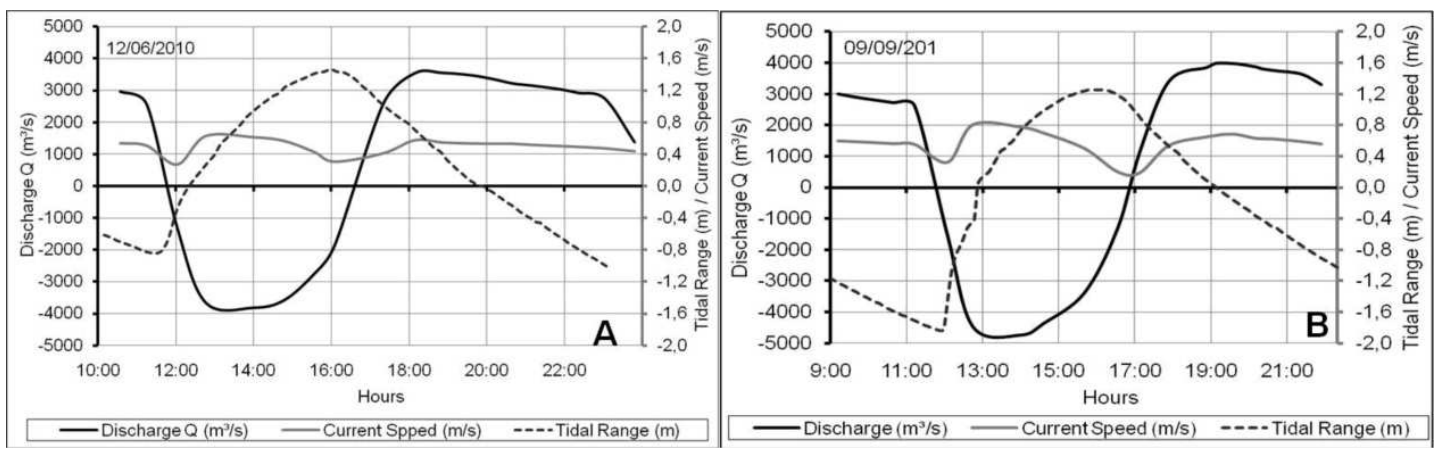

Fig. 8. Discharge, current velocities and water level variation at Capim River (km 108 - station 4b, Figure 01) A - 13 ${ }^{\text {th }}$ Jun 2010 - rainy-dry seasons transition and B $-09^{\text {th }}$ Sep 2010 - dry season. 
If instantaneous values are compared, discharges on the Capim River are continuously two to three times greater than on the Guamá River. During the ebb the discharge maximum is about 4,000 to $5,000 \mathrm{~m}^{3} / \mathrm{s}$ on the Capim River, whereas on the Guamá River it was always below $2,000 \mathrm{~m}^{3} / \mathrm{s}$.

Comparing the measurements carried out at points $5(\mathrm{~km} \mathrm{161)}$ and $6(\mathrm{~km} \mathrm{194)}$ along the Guamá River, the maintenance of the asymmetric pattern of the tide, including a significant reduction of the discharge magnitude from $\mathrm{km} 161$ to $\mathrm{km} \mathrm{194,} \mathrm{can} \mathrm{be}$ observed. However, the current velocities seen at $\mathrm{km}$ 194 are greater. For instance, the topographical- geological effects at point $5(\mathrm{~km} 161$ - city of São Miguel do Guamá) are attributed to bedrock outcrops which seem to lead to a substantially greater mean depth and a consequent reduction in velocity (Fig. 10).

Nevertheless, the results presented in Figure 10A were taken under mean-discharge conditions and the measurements presented in Figure 10B were taken during the low-discharge period and under equinoctial influence. Thus, the higher current velocities, especially during the flood, observed in Figure 10B $(\mathrm{km} \mathrm{194})$, in relation to those in Figure 10A (km 161), are also the result of the more intense tidal incursion into the system during low-discharge periods.
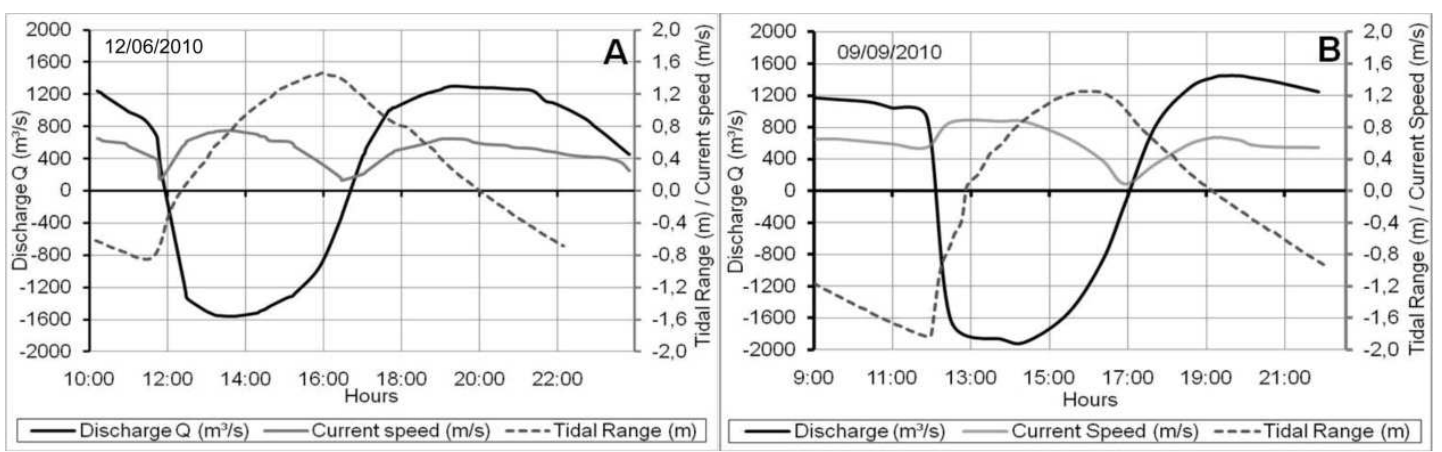

Fig. 9. Discharge, current velocities and water level variation at Guamá River (km 108 - station 4a, Figure 01) A - $13^{\text {th }}$ Jun 2010 - rainy-dry seasons transition and B $-09^{\text {th }}$ Sep 2010 - dry season.
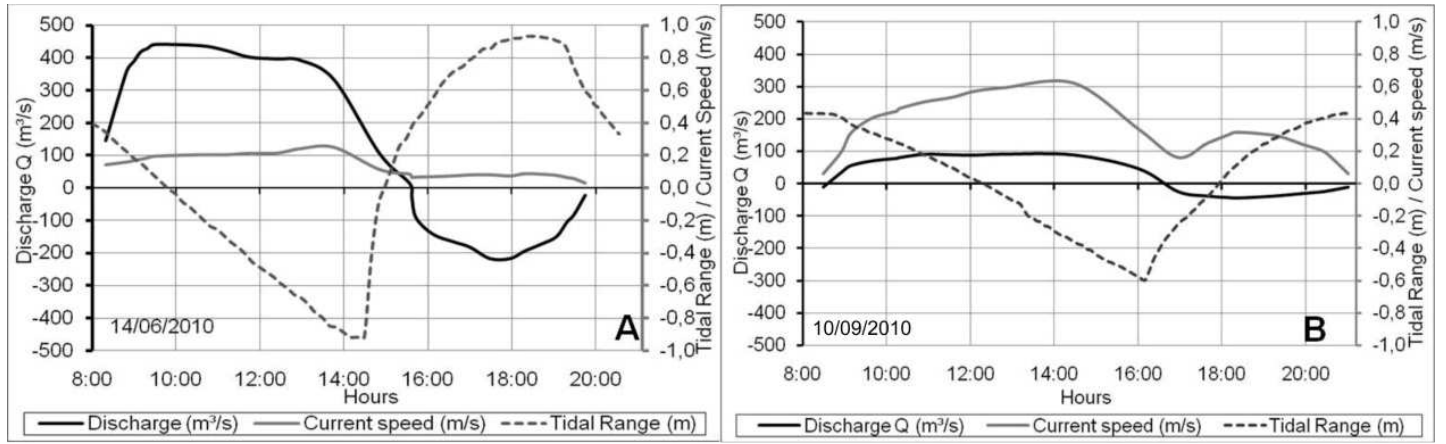

Fig. 10. Discharge, current velocity and water-level variation at Guamá River (A - km 161 - station 5, Figure 01) $14^{\text {th }}$ Jun 2010 - rainy-dry season transition and (B - km 194 station 6, Figure 01) 10 $0^{\text {th }}$ Sep 2010 - dry season.

\section{Seasonal Hydrodynamics at the Tidal River Mouth}

To better evaluate the seasonal variations of tidal propagation in the Guamá-Capim tidal river system, measurements were also taken in four different situations at the river mouth (point 2), during spring tides.

In this sector the hydrodynamic seasonal variation is small, as a consequence of the reduced significance of the fluvial discharge, as compared to the tidal flow (Fig. 11). The results show that usually instantaneous velocities (cross-sectionally averaged current velocities) and discharges are observed during the flood. As a consequence of fluvial input, total discharge volume is higher during the ebb. Table 2 summarizes the maximum current velocity and discharge data observed during the ebb and flood phases for each seasonal period. 
Table 2. Maximum current velocities and discharges at Guamá River mouth.

\begin{tabular}{lllll}
\hline \hline $\begin{array}{l}\text { Period / Tidal } \\
\text { Phase }\end{array}$ & FLOOD & EBB & \\
\cline { 2 - 5 } & Max. Curr. Velocity $(\mathrm{m} / \mathrm{s})$ & Max. discharge $\left(\mathrm{m}^{3} / \mathrm{s}\right)$ & Max. Curr. Velocity (m/s) & $\begin{array}{l}\text { Max. discharge } \\
\left(\mathrm{m}^{3} / \mathrm{s}\right)\end{array}$ \\
\hline October/2008 & 1.156 & 20,000 & 1.105 & 15,000 \\
January/2009 & 1.200 & 19,000 & 1.110 & 16,000 \\
April/2009 & 1.265 & 22,000 & 1.252 & 18,500 \\
July/2009 & 1.169 & 20,500 & 1.181 & 17,000 \\
\hline
\end{tabular}

Maximum current velocities were slightly higher during the ebb only in July/2009, as a consequence of very high discharges observed during June-July of that year (Figs 2 and 3). For all observed situations the ebb phase lasted longer than the flood, with mean durations of 7.2 hours for the ebb and 5.1 hours for the flood.

During periods of low discharge (e.g. October/2008 - Figure 11A and January/2009 - Figure
11B) flow discharge and velocities are substantially higher during the flood, as tidal asymmetry suggests. However, during the high-discharge period (April/2009 - Figure 11C and July/2009 - Figure 11D), the differences in maximum velocities almost vanish, although there is still a greater maximum discharge during the flood. Furthermore, maximum velocities and discharges were observed during April and minimum ones in October, as expected.
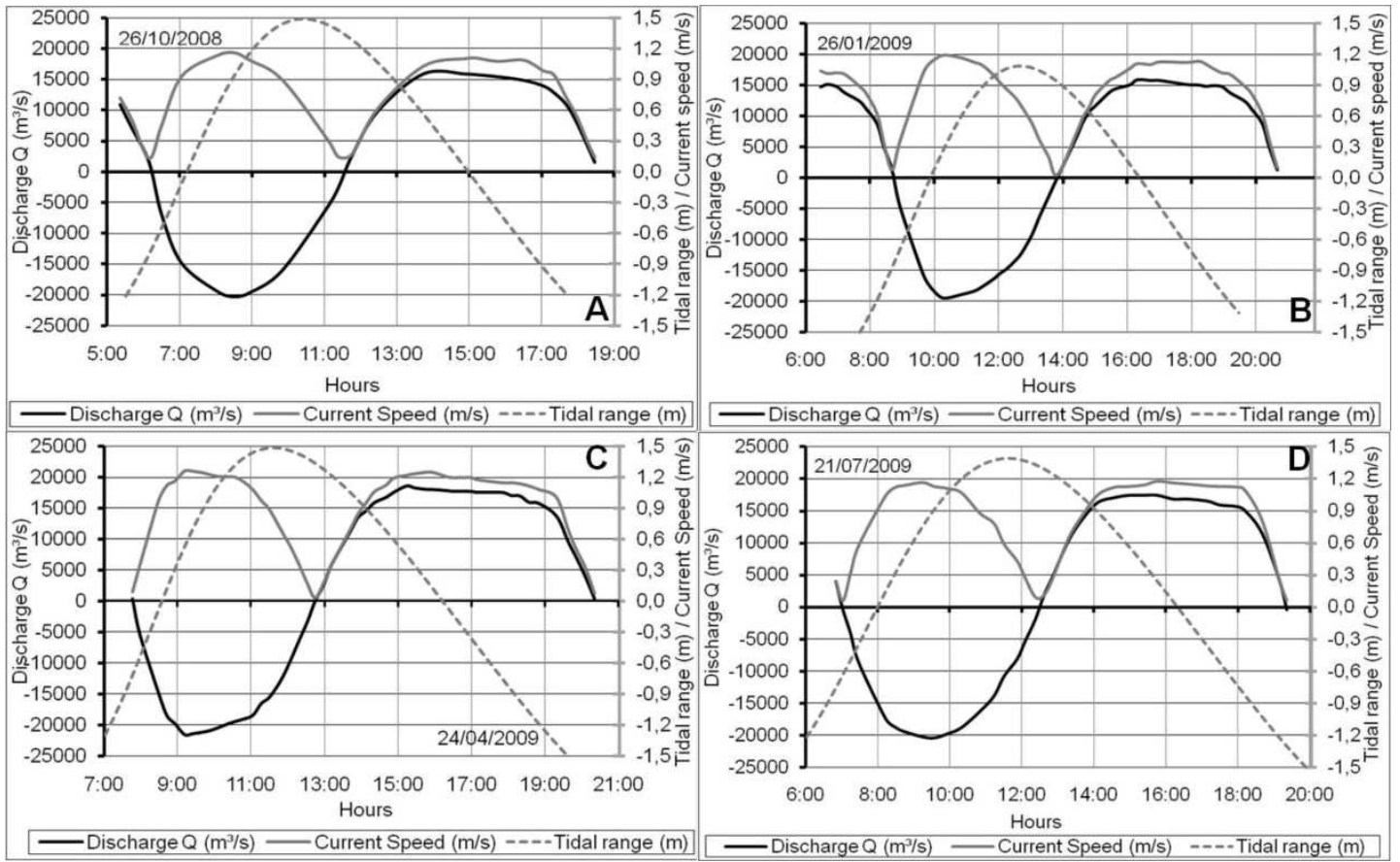

Fig. 11. Discharge, current velocities and water level prediction at spring tidal conditions at Guamá river mouth $\left(\mathrm{A}-26^{\text {th }}\right.$ Oct 2008, B $-26^{\text {th }}$ Jan 2009, C $-02^{\text {nd }}$ Apr 2009 and D $-21^{\text {st }}$ Jul 2009). 


\section{Drainage Basin Hypsometry}

Due to the relevance of the basin (channel) elevation for the upstream tidal propagation and of the catchment area for the fluvial discharge, hypsometric analysis of the study area was performed (Fig. 12).

If the two parts of the drainage basin are considered separately, it can be observed that the Capim River is around two times longer (Fig. 12B) and its drainage basin is around four times larger than that of the Guamá River (Fig. 12D). The entire system presents a catchment area of around $48,000 \mathrm{~km}^{2}$ and a maximal elevation of around $400 \mathrm{~m}$.

Evaluating the fluvial thalweg one can observe that long sectors (e.g. the first $200 \mathrm{~km}$ from the river mouth) of the channels are low and flat. Furthermore, after $210 \mathrm{~km}$ from the system mouth the Guamá River becomes more elevated than the Capim River (Fig. 12B).

As for mean altitudes, the values obtained, on the basis of the DEM undertaken, were: $95 \mathrm{~m}$ for the entire system and $59 \mathrm{~m}$ and $123 \mathrm{~m}$, respectively, for the Guamá and Capim basins.

Analyzing the basin's altitude in terms of hypsometric integral (area-elevation correlation), the values of 0.3 for the system as a whole, and 0.39 for the Capim and 0.41 for the Guamá basin were obtained. The general aspect of the two parts of the basin is, therefore, quite similar (Fig. 12C). Nevertheless, the slightly higher value of the hypsometric integral of the Guamá basin than of the
Capim basin is significant, since the usual limit for a basin to be classified as mature (in equilibrium) is 0.4 (STRAHLER, 1952).

\section{Discussion ANd Conclusions}

The spatial and temporal discharge variations observed are coherent with the differences registered in precipitation patterns and geometry (i.e. size and elevation) of the two sub-basins investigated. These differences were important for the tidal propagation along the Guamá-Capim system.

During its propagation upstream, the tidal wave can be greatly modified by the friction between the bed and the current and the funneling effect (DYER, 1995). If the frictional effects prevail, the tidal range and currents will be continuously reduced as they progress upstream and the estuary (or tidal river) is then classified as hyposynchronic.

Conversely, if there is a landward increment of the tidal range (and currents) along the tidal river (funneling effect), before the final attenuation due to fluvial discharge and elevation, then the system might be called hypersynchronous. If the tidal range does not change significantly along the low and middle sectors of the estuary, the system is considered synchronous, although this situation seems to be rare in nature (NICHOLS; BIGGS, 1985).

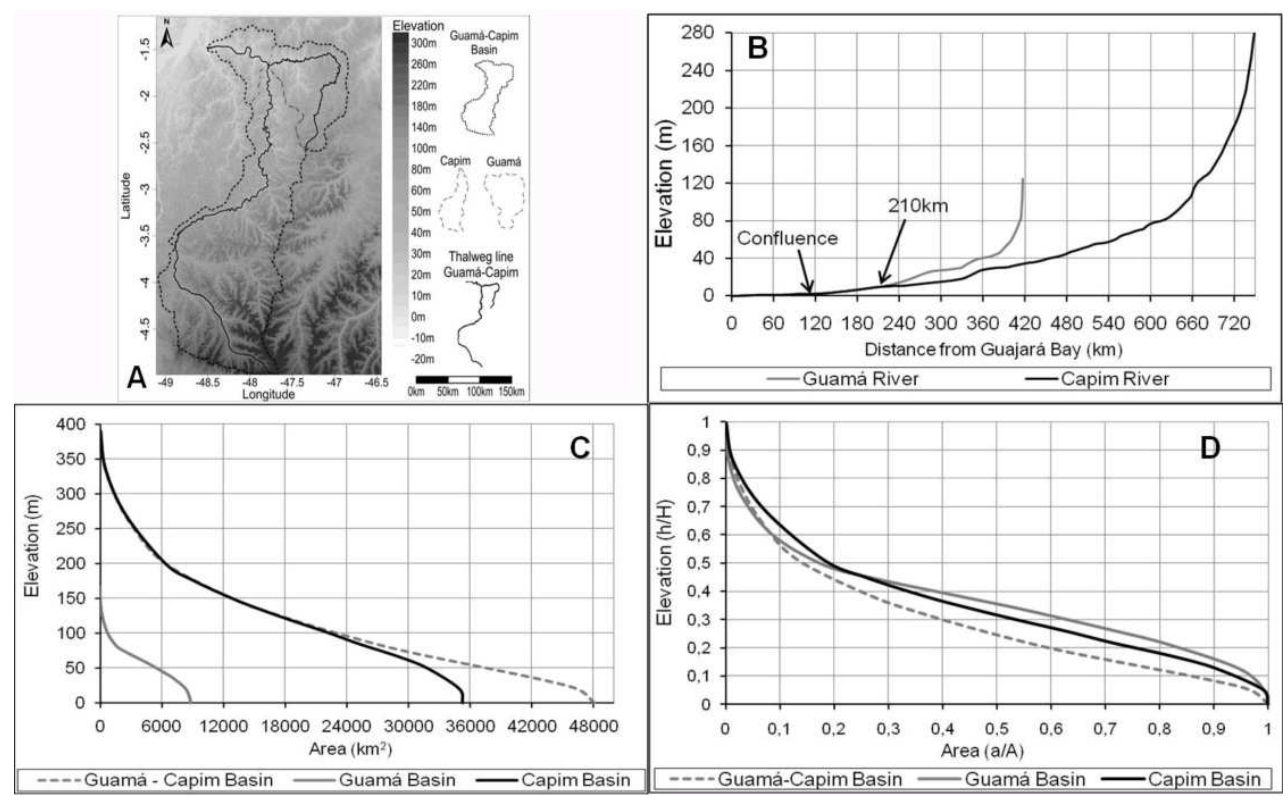

Fig. 12. (A) Elevation map, (B) Thalweg profiles of the Guamá and Capim Rivers. Relative (C) and absolute (D) basin hypsometry of the Guamá and Capim Rivers (see Figure 1 for location). 
When the tidal ranges measured along the Guamá-Capim tidal river are compared, it may be seen that hyposynchronic conditions were observed in both the dry and wet seasons. However, the distance between measuring stations is, in some cases, almost $50 \mathrm{~km}$. Hypersynchronic conditions might, thus, occur without being detected.

Results from the Amazon River (KOSUTH, et al., 2009) as well as from other estuarine systems along the north coast of Brazil (KJERFVE; FERREIRA, 1993; SANTOS et al., 2005) also show hyposynchronic conditions in systems with tidal bores and substantial fluvial inflow. For those systems with large catchment areas and consequently large fluvial inflow this seems to be the main cause of friction and reduction of tidal range. Even for the tide distortion, the fluvial discharge might be more significant than the narrowing of the channel (funneling effect). In estuarine systems with small fluvial discharge, friction of the bed accounts for the upward reduction in tidal range.

Furthermore, in the system analyzed there are significant variations depending on tidal range (spring-neap variation; equinox-solstice effects) and fluvial discharge. Under low- and mean-discharge situations, synchronicity, or even smooth hypersynchronicity, seems to occur on the Capim River (Fig. 6A). The results presented in Figure 4 also suggest the possibility of a hypersynchronic pattern for low-discharge periods. At the same time, under low fluvial discharge conditions and equinoctial effects (e.g. in September), the Guamá River seems to present a synchronic circulation pattern.

Besides the attenuation, a significant distortion of the tidal wave is observed along the system. Considering a spring tide during the highdischarge period on the Capim River ( $\mathrm{km} \mathrm{138),} \mathrm{the}$ ebb phase was more than $5 \mathrm{~h}$ longer than the flood phase. However, flood current velocities were not substantially higher and this is to be attributed to the fluvial discharge effect.

A flood-dominant response is typical of hypersyncronous estuaries, where the tidal range is large compared with the water depth (DYER, 1995). Despite a tidal range of more than $3 \mathrm{~m}$ at the river mouth, the channel is deep, up to 20 meters at the mouth with the mean depth oscillating between 5 and $8 \mathrm{~m}$ along most of the tide-affected sector. Thus the system can be considered deep (FRIEDRICHS; AUBREY, 1988) and a hypersynchronic response is not to be expected, although the system is likely to be flood-dominant.

As an exacerbation of this asymmetrical tide, field observations and reports of the local community attest that the tidal bore phenomenon occurs in the area, especially on the Capim River from $\mathrm{km} 108$ (point 4b) to the $\mathrm{km} 161$ (point 10), where the water level can rise by up to $3 \mathrm{~m}$ in few minutes.

Furthermore, the tidal bore phenomenon occurs in the area only during the conjunction of the high-discharge period (river flood) and equinoctial tides (e.g. March - April), although in this situation the attenuation of the tide is even more marked. Under these conditions, the tidal bore occurs as a breaking wave, but the occurrence of an undulating tidal bore is also expected during periods of extreme tidal ranges (equinox) and low fluvial discharge (e.g. September October).

To evaluate the propagation of the tide and the formation of the tidal bore in the area, it is necessary to consider both attenuation and distortion simultaneously. The tidal attenuation, in terms of tidal range reduction, and the tidal distortion, in terms of the asymmetry expressed by the difference in the duration of the ebb-flood phases, were, therefore, compared (Fig. 13).

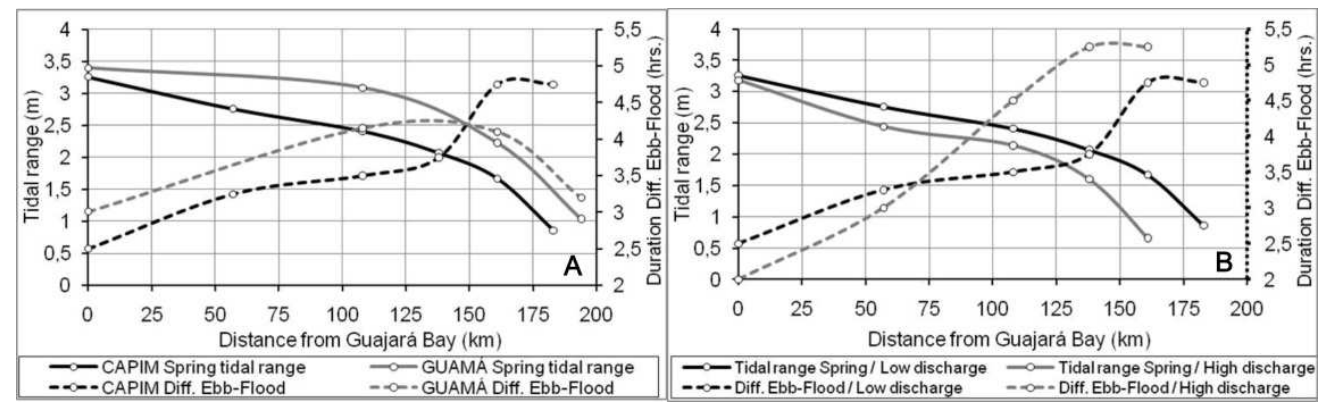

Fig. 13. Comparison of tidal phases' duration differences and tidal range along the Capim $\left(20^{\text {th }}-21^{\text {st }}\right.$ Dec 1998$)$ and Guamá $\left(09^{\text {th }}-10^{\text {th }}\right.$ Sep 2010) Rivers at low-discharge situation (A), and during low- $\left(20^{\text {th }}-21^{\text {st }}\right.$ Dec 1998$)$ and highdischarge (30 ${ }^{\text {th }}$ May 1999) periods at Capim River (B). 
It can be observed in Figure 13A that the reduction in tidal range occurs at a more intense rate on the Capim than on the Guamá branch during the low-discharge period. On the other hand, the measurements were taken in two different periods: in December 1998 on the Capim branch and in September 2010 on the Guamá branch. However, both correspond to the dry season/low discharge situation, and the data presented in Figures 2 and 3 have shown that the years compared, 1998 and 2010, were similar regarding precipitation and discharge pattern. The observed tidal range at the river mouth was only $6 \%$ higher in September 2010 (2.58 m), than in December $1998(2.43 \mathrm{~m})$. Therefore, the differences observed in the tidal attenuation and distortion within the branches are assumed to be the result of the general geomorphologic and hydrologic differences between the two branches/sub-basins.

As expected, Figure 13B shows that the upstream tidal range reduction is more significant during the high-discharge period on the Capim branch. However, the tide becomes rapidly and intensively more asymmetrical upstream in this situation. Therefore, in that situation the distortion of the tide is greater than its attenuation. This might be caused by intense and successive cross-sectional area reduction upstream (funneling effect) or even by the fluvial flow against the incoming tide.

As the reduction of the cross-sectional area is virtually the same during low- and high-discharge periods, the fluvial flow appears as a decisive factor for the increase of asymmetry and the occurrence of the tidal bore. Indeed, at points $4(\mathrm{~km} \mathrm{108)}$ and $10(\mathrm{~km}$ 138) on the Capim branch the tidal bore is observed during March-April (high discharge) at spring equinoctial tides.

On the other hand, there are no measurements or reports of the local community showing or making reference to the occurrence of the tidal bore during the spring equinoctial tides of September/October when fluvial discharge is low.

There were no available data on tidal range and phase duration for the Guamá branch under high discharges, but the results presented in Figure 13A suggest that the distortion on the Capim river branch is substantially higher than on the Guamá river branch in the distal portion of the tidal river, at the same time that the attenuation is greater on the Capim. This pattern seems to be more evident during the highdischarge period, since the tide distortion on the Capim branch is greatly intensified then.

As presented in Figure 13A, during spring equinoctial tides tidal bore formation would be possible during the low-discharge (dry) period on the Guamá river branch, since the tide advances more than $100 \mathrm{~km}$ upstream without significant attenuation. Again, fluvial discharge seems to play a major role as, during the dry season, the discharge of the Capim River is around 10 times greater than that of the Guamá River, thus, the tide incursion on the Guamá River might be intensified even during the lowdischarge period, but the distortion is reduced and tidal bores would not occur.

Kjerfve and Ferreira (1993) identified the occurrence of a tidal bore on the Mearim River (Maranhão State, Amazonian region) and considered the asymmetrical tide pattern, similar to the one described here, as responsible for the phenomenon. The authors have observed tidal bore formation during the low-discharge period, but have perceived that its formation is more intense during the high-discharge period. On the other hand, in that system the funneling effect is strong.

Fluvial discharge seems, therefore, to be more important for tidal asymmetry and tidal bore formation than the funneling effect on the GuamáCapim system. Although there is almost no increase in tidal range along the channel, tidal bore occurs.

Beyond the so-called funneling effect, of secondary relevance for the tidal propagation along the sector evaluated, the local geomorphology is important, especially in terms of the topography and hypsometry of the basins.

As has already been demonstrated, the drainage system is mostly of low relief, with few elevated areas surrounding the main river sources. This general configuration seems to be the main factor responsible for the substantial landward incursion of the tide in the Guamá-Capim river system.

The results indicate that under low-discharge conditions the spring tide reaches up to $220 \mathrm{~km}$ upstream on the Capim River, and around $200 \mathrm{~km}$ on the Guamá River. In the high-discharge period the reduction is of around $20 \%$, but even so tidal ranges of around $1 \mathrm{~m}$ are registered $160 \mathrm{~km}$ from the river mouth on the Capim River. Thus the present results extend the tidal influence about $50 \mathrm{~km}$ upstream, since previous studies have mentioned a tidal limit of around $161 \mathrm{~km}$ (point 5, São Miguel do Guamá city) from the mouth (GREGÓRIO; MENDES, 2009).

Besides, the geometry of the river channels (e.g. substantial and spatially-limited increase of sinuosity) suggests that the tidal influence reaches up to $230 \mathrm{~km}$ for the Guamá and $250 \mathrm{~km}$ for the Capim River, where both rivers present the same low elevation.

Furthermore, at the same time that the tidal river as a whole constitutes a fluvial-tidal transition zone (DALRYMPLE; CHOY 2007); there is rather a tidal limit zone than an absolute limit for tidal incursion. This is typical of the Amazonian region, as well as of other regions with marked seasonality, where the river flow varies significantly throughout the year, since spatial tidal action is strongly 
conditioned by river discharge, as already described by Kosuth et al. (2009) for the Amazon River.

The lesser reach of the tide on the Guamá than on the Capim River, despite the much larger fluvial discharge of the latter, could be explained by their basin hypsometry.

From km 210 upwards, the Guamá River is higher than the Capim. Furthermore, at km 161 (point 5) there is a substantial bedrock outcrop on the Guamá River bed, blocking almost the entire cross-section and resulting in a marked reduction of the local crosssectional area, thus substantially hindering the upstream advance of the tide. This effect would also explain the substantial reduction in the asymmetry along the Guamá branch from this point upwards. A similar effect is described by Wolanski et al. (2006) on the Daly estuary in Australia. The authors quoted report tidal bore formation only during the dry season on the Daly estuary, mainly due to the impounding of the estuary by shoals (WOLANSKI et al., 2006). This could also be the case of the Guamá River.

The slightly higher value of the hypsometric integral of the Guamá basin as compared to that of the Capim basin might also indicate that the former is younger and has less space to accommodate the rising tide. However, the relevance of hypsometric differences as between the Capim and Guamá river basins, in relation to the differences in the effect of fluvial discharges on tidal propagation calls for profound investigation.

Figures 14 and 15 summarize the results regarding tidal propagation along the Guamá and Capim Rivers, based on the scheme proposed by Dalrymple and Choi (2007), taking tidal distortion and attenuation/amplification in macrotidal estuaries into consideration.

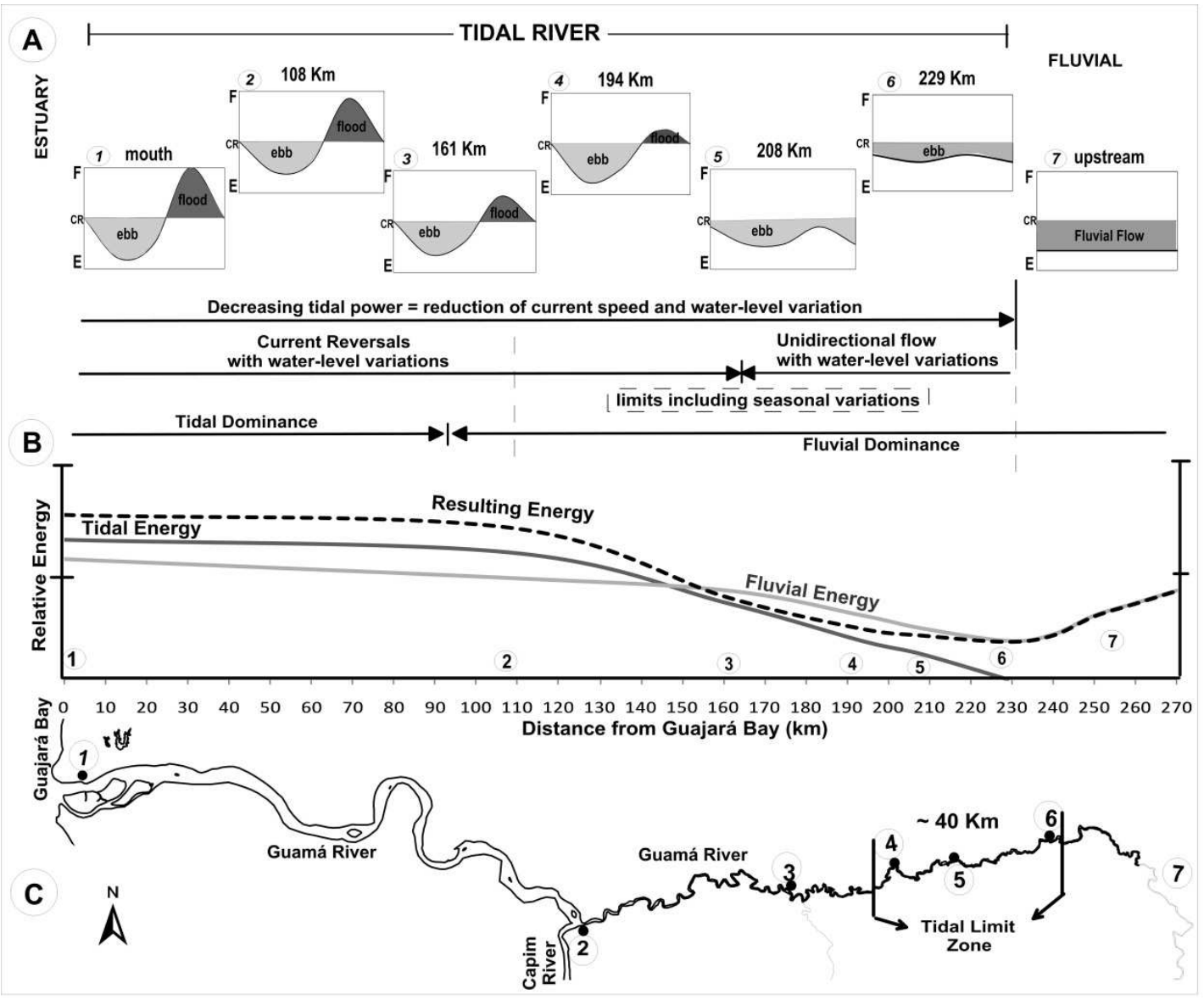

Fig. 14. (A) Schematic representation of the tidal action along the fluvial channel, showing the water-level variation and opposed the forces of river and tidal currents; $\mathrm{E}=$ seaward-directed (river and/or ebb) currents; F=landward-directed (flood) currents; $\mathrm{CR}=$ Currents Reversals. (B) Hydrodynamic longitudinal variation of tidal and river currents along the Guamá River. (C) Clipping of the study area (Guamá river branch) with emphasis on locations of measurements and tidal limit zone. (Modified from Dalrymple and Choi 2007). 


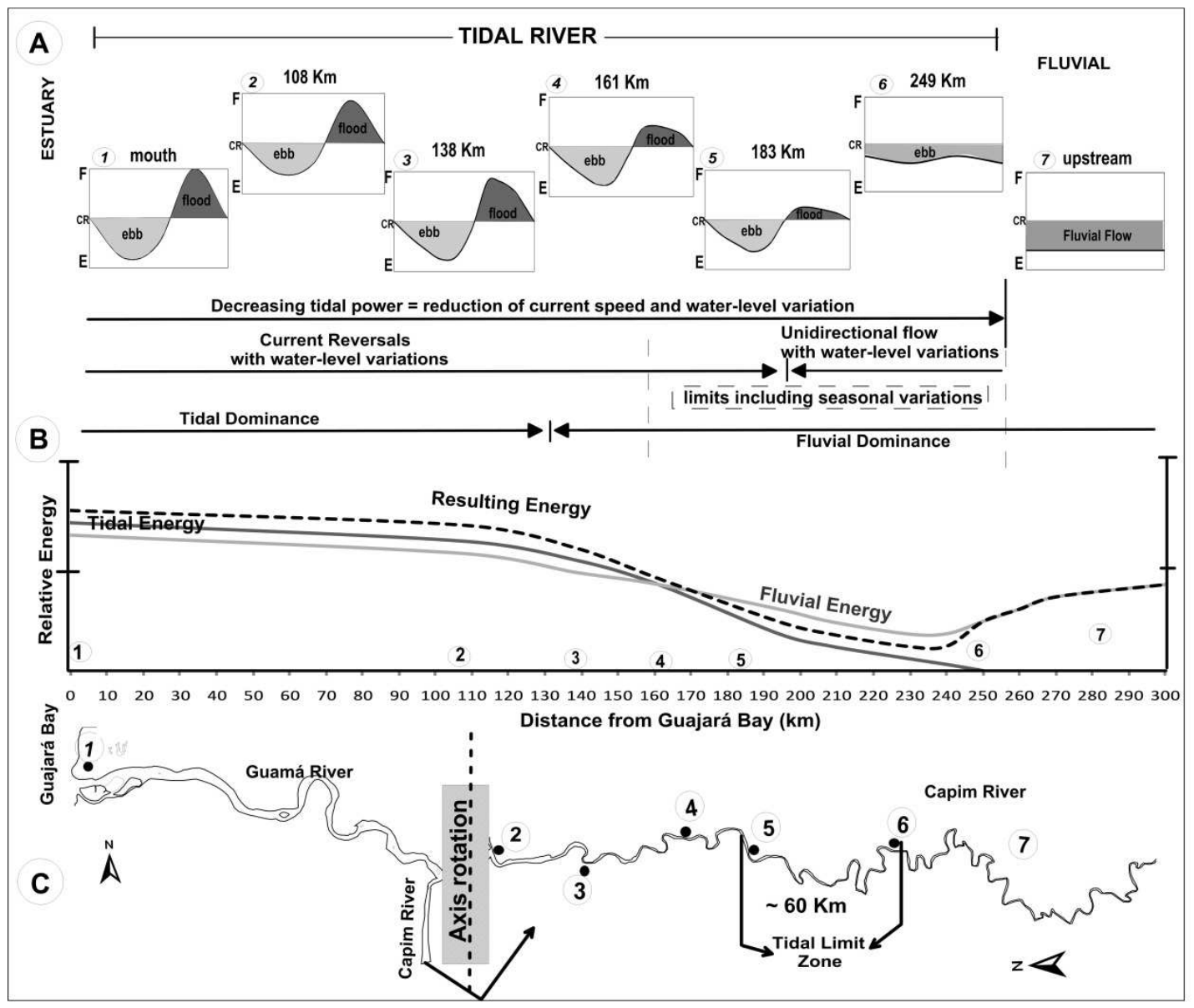

Fig. 15. (A) Schematic representation of the tidal action along the fluvial channel, showing the water-level variation and opposed the forces of river and tidal currents; E=seaward-directed (river and/or ebb) currents; F=landward-directed (flood) currents; $\mathrm{CR}=$ Currents Reversals. (B) Hydrodynamic longitudinal variation of tidal and river currents along the Capim River. (C) Clipping of the study area (Capim river branch) with emphasis on locations of measurements and tidal limit zone. (Modified from Dalrymple and Choi, 2007).

In general, the physical aspects of the system configuration and tidal propagation do not differ from those of typical macrotidal estuaries, thus justifying the use of Dalrymple and Choi's system (2007). It is, however, important to underline that the GuamáCapim river system is better classified as a tidal river.

Bokuniewicz (1995) has emphasized the difficulties involved in the attempt to reconcile hydrographic (salinity-based) classifications of estuaries with schemes based on geomorphological and sedimentological features. The distinction of a tidal river type of environment has emerged within this context (WELLS, 1995).

Tagliapietra et al. (2009) have conducted an extensive review of terms relating to estuaries and summarized the discussion regarding definitions in terms of two main concepts: the 'tidal concept' versus the 'brackish' concept, highlighting the Latin origin of the word 'estuary' as meaning essentially tide. Thus, tide incursion would be the main characteristic related to the definition of an estuary, instead of salt intrusion and dilution, as considered in hydrographic (salinitybased) classifications.

The very open definition of estuaries proposed by Kjerfve (1989) was considered the most suitable one by Tagliapietra et al. (2009): 'An estuarine system is a coastal indentation that has a restricted connection to the ocean and remains open at least intermittently' (KJERFVE, 1989).

In the light of that definition, all tidal rivers could be included as estuarine systems, but the results presented here have also demonstrated the need of such a category of estuarine systems as tidal rivers, with their own particular characteristics. 


\section{ACKNOWLEDGMENTS}

The authors would like to thank all those who have contributed to the publication of this study, especially the Coastal Geology Lab staff (UFPA/Bragança) and AHIMOR for their collaboration with the data collection. The first author would like to thank the State of Pará Research Foundation (FAPESPA) and VALE for their financial support in the form of a MSc. fellowship, which has also made this study possible. We also would like to thank the National Council for Scientific and Technological Development of Brazil (CNPq) for the grant of Prof. Dr. Nils E. Asp (501014/2009-8) and for the funding of the project 'Qualidade da Água e suas Implicações sobre o Sistema Homem - Ambiente na Amazônia (Ilha do Combu - Belém - PA), under the coordination of Prof. Dr. José Souto Rosa Filho MCT/CT-HIDRO/MMA/CNPq N² 29/2007.

\section{REFERENCES}

ANA - Agência Nacional de Águas. Hidroweb: Serviço de Informações Hidrológicas. May 2011. Available at < http://www2.ana.gov.br/Paginas/default.aspx > Access: May $05^{\text {th }}, 2011$.

BEZERRA, M. O.; MEDEIROS, C.; KRELLING A. P. M. ROSÁRIO R. P.; ROLLNIC, M. Physical oceanographic behavior at the Guamá/Acará-Mojú and the Paracauari river mouths, Amazon coast (Brazil). J. Coast. Res., SI, v.64, p. 1448-1452, 2011.

BOKUNIEWICZ, H. Sedimentary systems of costal-plain estuaries. In: PERILLO, G. M. E. (Ed.). Geomorphology and Sedimentology of estuaries. Chap. 3. Amsterdam: Elsevier, 1995. (Developments in Sedimentology, 53. p. 49-68).

CAMERON, W. M.; PRITCHARD D. W. Estuaries. In HILL, M. N. (Ed.) The Sea. v. 2. Chichester: John Wiley and Sons, 1963. p. 306-324.

CARR, M. L.; REHMANN, C. R.; STOECKEL, J. A. PADILLA, D. K.; SCHNEIDER, D. W. Measurements and consequences of retention in a side embayment in a tidal river. J. Mar. Syst., v.49, p. 41-53, 2004.

CHAPPELL, J.; WOODROFFE, C. D. Macrotidal estuaries In: CARTER, R. W. G.; WOODROFFE, C. D. (Ed.) Coastal evolution: Late Quaternary shoreline morphodynamics, London: Cambridge University press, 1994. p. 187-218.

CHUN-YAN, L.; O'DONNELL, J. On the Exchange Flow in Tidal Rivers and Shallow Estuaries. Chin. J. Oceanol. Limnol., v.16, n.1, p. 1-8, 1998.

COHEN, B.; MCCARTHY, L. T. Salinity of the Delaware Estuary. Del. Geol. Survey, v.10, p. 1-41, 1963.

COOK, T. L.; SOMMERFIELD, S. K.; WONG, K. C. Observations of tidal and springtime sediment transport in the upper Delaware Estuary. Estuar. Coast. Shelf Sci. v.72, p. 235-246, 2007.

DALRYMPLE, R. W., ZAITLIN, B. A., BOYD, R. Estuarine facies models: conceptual basis and stratigraphic implications. J. Sediment. Petrol., v.62, p. 1130-1146, 1992.
DALRYMPLE, R. W.; CHOI, K. Morphologic and facies trends through the fluvial-marine transition in tidedominated depositional systems: A schematic framework for environmental and sequence-stratigraphic interpretation. Earth-Sci. Rev., v.81, p. 135-174, 2007.

DYER, K. R. Sediment transport processes in estuaries. In: PERILLO, G. M. E. (Ed.). Geomorphology and Sedimentology of estuaries. Amsterdam: Elsevier,1995. (Developments in Sedimentology, 53, p. 423-449).

EMEKA, N. C.; ANTIA, V. I.; UKPONG, A. J.; AMAH, E. A.; NTEKIM, E. E. U. A study on the Sedimentology of tidal rivers: Calabar and Great Kwa, S. E. Nigeria. Eur. J. Scient. Res., v.47, n.3, p. 370-386, 2010.

FRIEDRICHS, C. T.; AUBREY, D. G. Non-linear tidal distortion in shallow well-mixed estuaries: a Synthesis. Estuar. Coast. Shelf Sci., v. 27, p. 521-545, 1988.

GREGÓRIO, A. M. S.; MENDES, A. C.; Characterization of sedimentary deposits at the confluence of two tributaries of the Pará River estuary (Guajará Bay, Amazon); Continent. Shelf Res., v.29, p. 609-618, 2009.

HANSEN, D. V.; RATTRAY, M. New dimensions in estuary classification. Limnol. Oceanogr., v.11, n.3, p. 319-326, 1966.

JARVIS, A.; REUTER, H. I.; NELSON, A.; GUEVARA, E. Hole-filled SRTM for the globe, Version 4. Available from the CGIAR-CSI SRTM 90m Database (http://srtm.csi.cgiar.org), 2008.

KJERFVE, B. Coastal Lagoons (Chapter 1). In: B. KJERFVE , B. (Ed.). Coastal lagoon processes. Amsterdam: Elsevier, 1994. (Elsevier Oceanography Series, 60 , p. $2-8,1994)$.

KJERFVE, B.; FERREIRA, H. O. Tidal bores: First ever measurements. In: Ciência Cult., S. Paulo, v.45, n.2, p. 135-138, 1993.

KJERFVE, B.; MAGILL, K. E. Geographic and hydrodynamic characteristics of shallow coastal lagoons. Mar. Geol., v.88, p. 187-199, 1989.

KOSUTH, P.; CALLEDE, J.; LARAQUE, A.; FILIZOLA, N.; GUYOT, J. L.; SEYLER, P.; FRITSCH, J. M.; GUIMARÃES, V. Sea-tide effects on flows in the lower reaches of the Amazon River. Hydrol. Process., v.23, p. 3141-3150, 2009

LENTZ, S. J. The Amazon River plume during AMASSEDS: subtidal current variability and the importance of wind forcing. J. Geophys. Res., v.100, p. 2377-2390, 1995.

MARENGO, J. A.; NOBRE, C. A.; TOMASELLA, J.; CARDOSO, M. F.; OYAMA, M. D. Hydro-climatic and ecological behavior of the drought of Amazonia in 2005. Philos. T. Roy. Soc. B, v. 363, p. 1773-1778, 2011.

MEADE, R. H.; DUNNE, T.; RICHEY, J. E. Storage and remobilization of suspended sediment in the lower Amazon River of Brazil. Science, v. 228, p. 488-490, 1985.

MORAES, B. C.; COSTA, J. M. N.; COSTA, A. C. L.; COSTA, M. H. Variação espacial e temporal da precipitação no estado do Pará. Acta Amazonica, v. 35, p. 207-214. 2005

NICHOLS, M. M.; BIGGS, R. B. Estuaries. In: DAVIS R. A. (Ed.). Coastal sedimentary environments. New York: Springer-Verlag, 1985. p. 77-186.

PRITCHARD, D. W. Estuarine Circulation Patterns. Proceedings American Society Civil Engineering, v. 81, p. $1-11,1955$. 
PRITCHARD, D. W. What is an Estuary: Physical viewpoint In: LAUFF, G. H. (Ed.). Estuaries. Washington, D.C. American Association for the Advancement of Science, 1967. p. 3-5.

ROSSETTI, D. F.; SANTOS-JÚNIOR, A. E. Facies architecture in a tectonically influenced estuarine incised valley fill of Miocene age, northern Brazil. J. South Am. Earth Sci., v. 17, p. 267-284, 2004.

SANTOS, V. F.; FIGUEIREDO JR., A. G.; SILVEIRA, O. F. M.; POLIDORI, L.; OLIVEIRA, D. M.; DIAS, M. B.; SANTANA, L. O. Processos sedimentares em áreas de macromarés influenciados pela pororoca - estuário do rio Araguari-Amapá-Brasil. In: CONGRESSSO DA ASSOCIAÇÃO BRASILEIRA DE ESTUDOS DO QUATERNÁRIO, 10, 2005. Anais... Guarapari: ABEQUA, 2005. Artigos, 6p. CD-ROM.

SHIH, D. C. F. Identification of phase propagation of water level in tidal river by spectral analysis. Stochastic environmental research and risk assessment. New York: Springer-Verlag, 2002. v.16, p. 449-463.

SOUZA-FILHO, P. W . M · TOZZI, H. A M ; EL-ROBRINI, M. Geomorphology, land use and environmental hazard in Ajuruteua macrotidal sandy beach, northeastern Pará, Brazil. J. Coast. Res.,v. 35, p. 580-589, 2003.

SOUZA-FILHO, P. W. M.; LESSA, G. C.; COHEN, M. C. L.; COSTA, F. R.; LARA, R. J. The subsiding macrotidal barrier estuarine system of the eastern Amazon coast, Northern Brazil. In: DILLENBURG, S F., HESP, P. A. (Ed.). Geology and Geomorphology of Holocene coastal barriers of Brazil. New York: Springer-Verlag, 2009. (Lecture Notes in Earth Sciences, 107 , p. 347-376).
STRAHLER, A. N. Hypsometric (area-altitude) analysis of erosional topography. Bull. Geol. Soc. Am.,v. 63, p. 1117-1142, 1952

TAGLIAPIETRA, D.; MARCO SIGOVINI, M GHIRARDINI, A. V. A review of terms and definitions to categorise estuaries, lagoons and associated environments.Mar. Freshwat. Res., v.60, p. 497-509, 2009.

VRIEND, H. J. Advances in morphodynamics of tidal rivers and estuaries. In: INTERNATIONAL CONFERENCE ON ESTUARIES AND COASTS, 2003. China,. p. 3-10.

WELLS, J. T. Tide-dominated estuaries and tidal rivers. In: PERILLO, G. M. E. (Ed.). Geomorphology and Sedimentology of estuaries. Amsterdam: Elsevier,1995. (Developments in Sedimentology, 53, p. 179-205).

WOLANSKI, E; WILLIANS, D; HANERT, E. The sediment trapping efficiency of the macro-tidal Daly Estuary, tropical Australia. Estuar. Coast. Shelf Sci.,v.69, p. 291-298, 2006.

(Manuscript received 28 September 2011; revised 02 December 2012; accepted 03 December 2012) 